\title{
Hubungan antara Profilaksis Kotrimoksazol dan Prevalensi Toksoplasmosis pada Pasien HIV Positif di Jember (The Association Between Prophylactic Cotrimoxazole and the Prevalence Toxoplasmosis in HIV-Positive Patients in Jember)
}

\author{
Elly Febry Taufany ${ }^{1}$, Afifah Machlaurin ${ }^{1}$, Prihwanto Budi Subagio ${ }^{2}$ \\ ${ }^{1}$ Fakultas farmasi universitas Jember \\ ${ }^{2}$ Instalasi farmasi RSD dr. Soebandi Jember \\ Jalan kalimantan 37, Jember 68121 \\ e-mail korespondensi: machlaushol@yahoo.com
}

\begin{abstract}
Human immunodeficiency virus (HIV) is a virus that causes acquired immune deficiency syndrome (AIDS). HIV is a high mortality disease and the number of patients is increasing recent days. Based on dr. Soebandi Jember Hospital report in 2015, there were 1,492 HIV patients and 455 people received antiretroviral (ARV) therapy. Toxoplasmosis is one of opportunistic infections commonly found in HIV patients in central nervous system. WHO has issued guidelines for the use of cotrimoxazole as prophylaxis in HIV positive people. The purpose of this study was to determine the relationship between cotrimoxazole prophylaxis and the incidence of toxoplasmosis. This research was a case control study with retrospective approach and used chi-square analysis. The results showed that most patients were male (57\%), 20-29 years in age (50\%), and 41-60 kg in weight (64\%). Based on the CD4 level, most HIV patients were less than $350 / \mathrm{mm}^{3}$ (96\%) and total lymphocite count (TLC) also less than $1,200 / \mathrm{mm}^{3}$ (42\%). There were 1 patient from 76 patients with cotrimoxazole prophylaxis and 7 patients from 52 patient without cotrimoxazole prophylaxis who developed toxoplasmosis. Based on chi-square analysis, cotrimoxazole prophylaxis reduce the incidence of toxoplasmosis in HIV positive ( $p$-value 0,004).
\end{abstract}

Keywords: HIVIAIDS, prophilaxis therapy of cotrimoxazole, toxoplasmosis infection

\begin{abstract}
Abstrak
Human immunodeficiency virus (HIV) merupakan virus yang menyebabkan acquired immune deficiency syndrome (AIDS). HIV adalah penyakit dengan angka kematian yang tinggi. Jumlah penderita yang meningkat dalam waktu singkat. Berdasarkan data rekam medik di dr. Soebandi Jember tahun 2015 jumlah pasien HIV 1,492 orang dan 455 diantaranya menerima terapi antiretroviral (ARV). Toksoplasmosis adalah infeksi oportunistik yang sering dijumpai pada penderita HIV sistem saraf pusat. WHO sudah mengeluarkan pedoman penggunaan kotrimoksazol sebagai terapi profilaksis pada orang dengan HIV positif. Tujuan penelitian ini adalah untuk mengetahui hubungan terapi profilaksis kotrimoksazol terhadap tingkat kejadian toksoplasmosis. Penelitian ini merupakan penelian case control secara retrospektif menggunakan chi-square. Hasil yang diperoleh menunjukkan sebagian besar pasien adalah laki-laki $(57 \%)$ usia $20-29$ tahun $(50 \%)$ dengan berat badan $41-60 \mathrm{~kg}(64 \%)$. Berdasarkan kadar CD4 sebagian besar pasien memiliki kadar CD4 $<350 / \mathrm{mm}^{3}(96 \%)$ dan kadar total limfosit (TLC) $<1,200 / \mathrm{mm}^{3}(11,1 \%)$. Terdapat 1,3\% pasien dengan profilaksis kotrimoksazol dan 13,5\% pasien tanpa profilaksis kotrimoksazol. Hasil analisis chi-square profilaksis kotrimoksazol dapat mengurangi kejadian toksoplasmosis pada HIV positif ( $p$-value 0,004$)$.
\end{abstract}

Kata kunci: HIVIAIDS, terapi profilaksis kotrimoksazol, infeksi toksoplasmosis 


\section{Pendahuluan}

Human immunodeficiency virus (HIV) adalah sejenis virus yang menyerang atau menginfeksi sel darah putih yang menyebabkan turunnya kekebalan tubuh manusia sedangkan acquired immune deficiency syndrome (AIDS) adalah sekumpulan gejala penyakit yang timbul karena turunnya kekebalan tubuh yang disebabkan infeksi HIV. Jumlah orang yang terjangkit HIV di dunia pada tahun 2013 sebanyak 35 juta orang dan jumlah kematian akibat AIDS sebanyak 1,5 juta [1]. Indonesia sendiri jumlah kasus HIVIAIDS pada September 2014 sebanyak 150,285 kasus HIV dan 55,799 kasus AIDS, sedangkan jumlah kasus HIV di provinsi Jawa Timur sebanyak 19,249 kasus dan jumlah kasus AIDS sebanyak 8,976 kasus [2]. Presentase untuk Kabupaten Jember dari data yang ada di klinik voluntary counseling testing (VCT) pada tahun 2004-2013 sebanyak 33 kasus HIV positif pada kelompok pelajar/mahasiswa, sedangkan kasus HIV positif pada kelompok ibu rumah tangga (IRT) sebanyak 377 kasus [3].

Pada penderita HIV positif mengalami gangguan dalam sistem imunitas terutama terjadi defisit jumlah sel CD4 sehingga mudah terkena infeksi parasit dan jamur oportunistik. Parasit dan jamur yang sering dijumpai pada penderita HIV positif sistem saraf pusat adalah toxoplasma gondii yang dapat menyebabkan toksoplasmosis [4]. Makin meningkatnya jumlah penderita HIV positif maka jumlah kasus toksoplasmosis ini juga semakin meningkat, sekitar 3-4\% dari penderita HIV positif menderita toksoplasmosis. Infeksi ini sering kali merupakan komplikasi pada penderita HIV stadium lanjut dan biasanya terjadi saat kadar CD4 kurang dari 100/mm $\mathrm{m}^{3}$ [5].

Pasien HIV positif mengalami infeksi oportunistik jika nilai CD4 turun, untuk menghindari terjadinya infeksi oportunistik dapat dilakukan pencegahan/profilaksis, WHO sudah mengeluarkan pedoman yang mengusulkan penggunaan kotrimoksazol sebagai terapi profilaksis pada orang dengan HIV positif dewasa dan anak [6]. Kotrimoksazol adalah kombinasi dua obat antibiotik yaitu trimetoprim dan sulfametoksazol yang merupakan pengobatan alternatif untuk toksoplasmosis karena murah, ditoleransi dengan baik, dan seefektif pirimetamin dan sulfadiazin yang merupakan lini pertama rejimen obat untuk penyakit toksoplasmosis [7].
Berdasarkan latar belakang di atas, maka diperlukan penelitian untuk mengetahui hubungan terapi profilaksis kotrimoksazol terhadap tingkat kejadian toksoplasmosis pada pasien HIV positif di klinik VCT RSD dr. Soebandi Jember Tahun 2015.

\section{Metode Penelitian}

Penelitian ini dilakukan dengan mencatat data rekam medik kesehatan (RMK). Penelitian dilakukan di RSD dr. Soebandi Jember mulai bulan Mei-Juli 2016. Populasi dalam penelitian ini adalah seluruh pasien dengan diagnosa HIV positif di RSD dr. Soebandi Jember tahun 2015. Sampel penelitian ini adalah sampel yang memenuhi kriteria inklusi yang mendapatkan perawatan di RSD dr. Soebandi Jember tahun 2015.

Teknik pengambilan sampel pada penelitian ini menggunakan teknik total sampling. Dengan jumlah populasi 220 pasien, diperoleh sampel sebanyak 128 pasien. Bahan penelitian ini adalah rekam medik kesehatan di instalasi rawat jalan pasien yang dibagi atas kriteria inklusi dan eksklusi.

Lembar pengumpulan data (LPD) dibuat rekap dalam sebuah tabel induk, kemudian analisis secara deskriptif mengenai hubungan terapi profilaksis kotrimoksazol terhadap tingkat kejadian toksoplasmosis di RSD dr. Soebandi Jember tahun 2015. Analisis data diperoleh dari lembar pengumpulan data dan dianalisis secara deskriptif. Untuk mengetahui hubungan varibel bebas terhadap variabel terikat digunakan analisis dengan menggunakan metode chisquare dengan tingkat kemaknaan $\mathrm{a}=0,05$.

\section{Hasil Penelitian}

Penelitian ini dillakukan dengan mencatat data rekam medik pasien HIV positif di klinik VCT RSD dr. Soebandi Jember tahun 2015. Karakteristik pasien dalam penelitian ini meliputi jenis kelamin, usia dan parameter klinik.

Hasil penelitian menunjukkan jumlah pasien HIV positif laki-laki lebih banyak 73 (57\%) dibandingkan dengan pasien perempuan 55 (43\%). Dari 73 pasien laki-laki 3 pasien mengalami infeksi oportunistik toksoplasmosis dan 55 pasien perempuan 5 pasien mengalami infeksi oportunistik toksoplasmosis (Tabel 1).

Kelompok usia tertinggi pasien HIV positif dewasa yang di rawat di klinik VCT RSD dr. Soebandi Jember adalah rentang usia 20-29 tahun sebanyak 64(50\%). Rentang usia 20-29 
Taufany, et al, Hubungan antara Profilaksis Kotrimoksazol dan Prevalensi Toksoplasmosis pada Pasien..

tahun 2 pasien mengalami infeksi oportunistik toksoplasmosis (Tabel 1).

Tabel 1. Karakteristik pasien HIV positif

\begin{tabular}{|c|c|c|c|}
\hline \multirow{2}{*}{ Profil pasien } & \multirow{2}{*}{$\begin{array}{l}\text { Jumlah } \\
\text { pasien }\end{array}$} & \multicolumn{2}{|c|}{ Toksoplasmosis } \\
\hline & & Ada & Tidak ada \\
\hline \multicolumn{4}{|l|}{$\begin{array}{l}\text { Demografi Pasien } \\
\text { Jenis kelamin }\end{array}$} \\
\hline Perempuan & $55(43 \%)$ & $5(9,1 \%)$ & $50(90,9 \%)$ \\
\hline Laki-laki & $73(57 \%)$ & $3(4,1 \%)$ & $70(95,9 \%)$ \\
\hline \multicolumn{4}{|l|}{ Usia (tahun) } \\
\hline$<19$ & $3(2 \%)$ & $0(0 \%)$ & $3(100 \%)$ \\
\hline $20-29$ & $64(50 \%)$ & $2(3,1 \%)$ & $62(96,8 \%)$ \\
\hline $30-39$ & $39(31 \%)$ & $4(10,2 \%)$ & $35(89,7 \%)$ \\
\hline $40-49$ & $14(11 \%)$ & $1(7,1 \%)$ & $13(92,8 \%)$ \\
\hline$>50$ & $8(6 \%)$ & $1(12,5 \%)$ & $7(87,5 \%)$ \\
\hline \multicolumn{4}{|l|}{ Parameter klinik } \\
\hline Berat badan $(\mathrm{kg})$ & $23(18 \%)$ & $4(17,3 \%)$ & $19(82,6 \%)$ \\
\hline $20-40$ & $82(64 \%)$ & $4(4,8 \%)$ & $78(95,1 \%)$ \\
\hline $\begin{array}{l}41-60 \\
61-80\end{array}$ & $21(16 \%)$ & $0(0 \%)$ & $21(100 \%)$ \\
\hline $\begin{array}{l}01-80 \\
81-100\end{array}$ & $1(1 \%)$ & $0(0 \%)$ & $1(100 \%)$ \\
\hline $\begin{array}{l}81-100 \\
>100\end{array}$ & $1(1 \%)$ & $0(0 \%)$ & $1(100 \%)$ \\
\hline \multicolumn{4}{|l|}{ CD4 (/mm3) } \\
\hline$<350$ & $123(96 \%)$ & $8(6,5 \%)$ & $115(93,5 \%)$ \\
\hline$>350$ & $5(4 \%)$ & $0(0 \%)$ & $5(100 \%)$ \\
\hline \multicolumn{4}{|l|}{ Limfosit (/mm3) } \\
\hline$<1200$ & $54(42 \%)$ & $6(11,1 \%)$ & $48(88,9 \%)$ \\
\hline $1201-1500$ & $21(16 \%)$ & $2(9,5 \%)$ & $19(90,5 \%)$ \\
\hline $1501-1800$ & $14(11 \%)$ & $0(0 \%)$ & $14(100 \%)$ \\
\hline $1801-2100$ & $7(6 \%)$ & $0(0 \%)$ & $7(100 \%)$ \\
\hline$>2100$ & $32(25 \%)$ & $0(0 \%)$ & $32(100 \%)$ \\
\hline
\end{tabular}

Hasil penelitian menunjukkan persentase rentang berat badan tertinggi adalah kelompok pasien dengan berat badan $41-60 \mathrm{~kg}$ sebanyak 82(64\%). Rentang berat badan 41-60 $\mathrm{kg} 4$ pasien mengalami infeksi oportunistik toksoplasmosis (Tabel 1).

Hasil penelitian menunjukkan sebagian besar pasien dengan kadar CD4 $<350 / \mathrm{mm}^{3}$. Kadar CD4 $<350 / \mathrm{mm}^{3}$ dengan 123(96\%) 8 pasien mengalami infeksi oportunistik toksoplasmosis (Tabel 1).

Indikator lain yang digunakan dalam menentukan status imun pada penderita HIV positif adalah jumlah limfosit. Hasil penelitian menunjukkan bahwa persentase terbanyak adalah pasien dengan kadar limfosit $<1200 / \mathrm{mm}^{3}$ $54(41 \%)$. Rentang kadar limfosit $<1200 / \mathrm{mm}^{3} 6$ pasien mengalami infeksi oportunistik toksoplasmosis (Tabel 1).

Hasil penelitian menunjukkan pasien yang menggunakan kotrimoksazol sebanyak 76 (59\%) sebagai kelompok case dan tanpa kotrimoksazol sebanyak 52(41\%) sebagai kelompok control. Kelompok case 76 pasien 1 pasien mengalami infeksi oportunistik toksoplasmosis dan kelompok control 52 pasien 7 pasien mengalami infeksi oportunistik toksoplasmosis (Tabel 2).

Tabel 2. Profil terapi profilaksis kotrimoksazol pasien HIV positif

\begin{tabular}{ccccc}
\hline $\begin{array}{c}\text { Terapi profilaksis } \\
\text { toksoplasmosis }\end{array}$ & $\begin{array}{c}\text { Jumlah } \\
\text { pasien }\end{array}$ & Ada & $\begin{array}{c}\text { Toksoplasmosis } \\
\text { ada }\end{array}$ & $P$-value \\
& & & Adak & \\
\hline
\end{tabular}

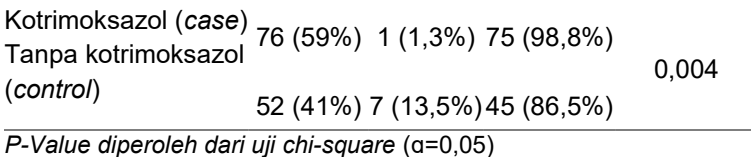

\section{Pembahasan}

Berdasarkan hasil penelitian laki-laki memiliki resiko HIV positif lebih tinggi dibandingkan dengan perempuan karena faktor perilaku yang dilakukan laki-laki diantaranya (1) perilaku seksual yang beresiko terhadap penularan HIV, yang meliputi partner hubungan seks lebih dari satu, seks anal, dan seks tanpa pemakaian kondom; (2) resiko parenteral, yaitu faktor resiko penularan HIV yang berkaitan dengan pemberian cairan kedalam tubuh melalui pembuluh darah vena, faktor ini meliputi riwayat transfusi darah, pemakaian narkotika dan obat-obatan terlarang (narkoba) secara suntik (injecting drug users); (3) faktor resiko infeksi menular seksual (IMS), yaitu riwayat penyakit infeksi bakteri atau virus yang ditularkan melalui hubungan seksual yang pernah diderita seperti sifilis, candiloma aciminata dan gonorrhoe [8].

Hasil penelitian berdasarkan usia tertinggi yaitu usia 20-29 tahun di susul dengan usia 30-39 tahun. Rentang usia 15-49 tahun merupakan rentang usia produktif secara ekonomi, rentan aktif seks bebas dan narkotika. $\mathrm{Hal}$ ini diakibatkan oleh rendahnya pengetahuan masyarakat tentang seks bebas sehingga tingginya jumlah pelaku seks menyimpang dan berganti-ganti pasangan serta tingginya angka penggunaan jarum suntik secara bergantian pada pasien yang menggunakan narkotika dan obat-obat terlarang. Pengetahuan mereka yang kurang tentang kesehatan dan rendahnya kesadaran mereka untuk memeriksakan diri di klinik VCT menyebabkan tingginya prevalensi penderita HIV [9].

Hasil berdasarkan berat badan tertinggi yaitu 41-60 kg. Berat badan yang tercantum pada hasil penelitian merupakan berat badan 
pasien saat awal terdiagnosis HIV. Hal ini akan mengalami penurunan maupun peningkatan seiring dengan perkembangan kondisi pasien dan gejala-gejala yang ditimbulkannya. Penurunan berat badan sangat umum terjadi pada pasien HIV positif [10]. Tanda-tanda utama HIV positif yaitu penurunan berat badan, demam dan berkeringat hebat pada malam hari, diare terus menerus, pembengkakan kelenjar pada leher dan ketiak, batuk secara terus menerus sehingga dapat terjadi pneumonia, tuberkulosis (TBC), cytomegalovirus, disfungsi hati, dan gangguan sistem saraf pusat (toksoplasmosis) [11].

Hasil penelitian menunjukkan kadar CD4 tertinggi adalah $<350 / \mathrm{mm}^{3}$. WHO menyatakan bahwa pasien dengan jumlah CD4 $<350 / \mathrm{mm}^{3}$ dianjurkan memulai terapi ARV [12]. Jumlah CD4 normal pada orang sehat berkisar antara $500 / \mathrm{mm}^{3}$ sampai $1.500 / \mathrm{mm}^{3}$ [13]. Sistem kekebalan tubuh pasien dengan jumlah CD4 $<200 / \mathrm{mm}^{3}$ akan mengalami penurunan sehingga pasien tersebut memiliki kerentanan enam kali untuk terkena infeksi oportunistik dibandingkan dengan pasien yang memiliki jumlah CD4 $>350 / \mathrm{mm}^{3}$, dengan demikian dapat dikatakan bahwa jumlah CD4 yang rendah menyebabkan individu lebih rentan terkena infeksi oportunistik [14]. Hal ini terbukti dari kecepatan penurunan CD4 yang dipakai sebagai petunjuk perkembangan penyakit AIDS, penurunan CD4 dari waktu kewaktu rata-rata $100 / \mathrm{mm}^{3} /$ tahun Pemeriksaan CD4 yang dianjurkan adalah setiap 6 bulan [15]. Rata-rata penurunan CD4 adalah sekitar $70-100 / \mathrm{mm}^{3} /$ tahun pada dewasa, dengan pemberian ARV akan meningkat sekitar 50-100/mm $3 \mathrm{~m}^{3}$ tahun [16].

Kadar limfosit tertinggi yaitu $<1200$. Jumlah limfosit $>2000$ setara dengan CD4 $>500$, jumlah limfosit 1000-2000 setara dengan CD4 200-500 dan jumlah limfosit $<1000$ setara dengan CD4 <200 [17]. Pemeriksaan jumlah limfosit merupakan standart untuk menilai dan menentukan derajat imunodefisiensi, penurunan progresif limfosit berhubungan dengan progresifitas CD4, namun penggunaan kadar limfosit sebagai pengganti jumlah CD4 tidak dianjurkan karena hanya mempresentasikan separuh data [18].

Kotrimoksazol merupakan terapi profilaksis primer toksoplasmosis pada pasien HIV positif [19]. Profilaksis kotrimoksazol memiliki efektivitas mengurangi mortalitas dan morbiditas pasien HIV positif terhadap infeksi toksoplasmosis terutama dengan jumlah CD4 $<350 / \mathrm{mm}^{3}$ [6]. CD4 pada pasien dengan jumlah $150 / \mathrm{mm}^{3}$ mengalami peningkatan sebesar $2-5 \%$ dengan profilaksis kotrimoksazol. Selain itu stadium klinik tipe 3 dan 4 juga mengalami peningkatan jumlah CD4 karena profilaksis kotrimoksazol [20].

Dari hasil statistika dengan menggunakan chi-square menunjukkan bahwa pemberian profilaksis kotrimoksazol pada pasien HIV positif berpengaruh pada tingkat kejadian toksoplasmosis ( $p$-value 0,004). Infeksi oportunistik merupakan infeksi mikroorganisme akibat timbul pada kondisi-kondisi tertentu yang memungkinkan. Secara klinik jumlah CD4 digunakan sebagai pertanda munculnya infeksi oportunistik pada penderita HIV positif. Infeksiinfeksi oportunistik umumnya terjadi bila jumlah CD4 $<200 / \mathrm{mm}^{3}$, salah satu infeksi oportunistik yang dapat menyerang pasien HIVIAIDS adalah toksoplasmosis [21]. Toksoplasmosis merupakan penyebab paling sering dari kelainan susunan saraf pusat pada penderita HIV positif [22].

\section{Simpulan dan Saran}

Pasien HIV positif terbanyak adalah lakilaki dengan rentang usia 20-29 tahun dan berat badan 41-60 kg. Kebanyakan pasien memiliki kadar CD4 $<350 / \mathrm{mm}^{3}$ dan kadar limfosit $<1200 / \mathrm{mm}^{3}$. Dari 76 pasien yang menerima profilaksis kotrimoksazol 1 pasien mengalami infeksi oportunistik toksoplasmosis, 52 pasien yang tidak menerima profilaksis kotrimoksazol sebanyak 7 pasien mengalami infeksi oportunistik toksoplasmosis. Terapi profilaksis kotrimoksazol dapat memenuhi tingkat kejadian infeksi oportunistik toksoplasmosis pada pasien HIV positif ( $p$-value 0,004).

Berdasarkan kesimpulan diatas disarankan untuk dilakukan penelitian yang sejenis secara prospektif agar dapat memberikan hasil penelitian yang lebih seksama. Terapi yang diberikan selain secara empiris sebaiknya juga dilanjutkan dengan terapi secara terarah, dengan cara mengetahui bakteri penyebab infeksi secara pasti dan kerentanan bakteri pada antibiotik tertentu, sehingga terapi yang diberikan bisa lebih optimal dan terjadinya resistensi bakteri penyebab infeksi dapat ditekan. 


\section{Daftar Pustaka}

[1] Indonesia. Kementerian Kesehatan Republik Indonesia. Situasi dan analisis HIV AIDS. Jakarta: Kementerian Kesehatan Republik Indonesia; 2014.

[2] Indonesia. Kementerian Kesehatan Republik Indonesia. Statistik kasus HIVIAIDS di Indonesia. Jakarta: Kementerian Kesehatan Republik Indonesia; 2013.

[3] Ningtyas B K, Makhmudah M, Hayyuning J. Strategi implementasi kebijakan penanggulangan penyakit menular HIVIAIDS di Kabupaten Jember dalam upaya percepatan pencapaian millenium development goals 2015. Fakultas IImu Sosial dan IImu Politik Universitas Brawijaya. 2015.

[4] Kurniawan A, Wahyuningsih R, dan Susanto L. Infeksi parasit dan jamur pada pasien terinfeksi HIV. Jakarta: Departemen Parasitologi Fakultas Kedokteran Universitas Indonesia dan Bagian Parasitologi Fakultas Kedokteran Universitas Kristen Indonesia; 2008.

[5] Sugianto P. Infeksi toksoplasmosis pada sistem saraf pusat, dalam: infeksi pada sistem saraf. Surabaya: Airlangga University Press; 2011.

[6] Switzerland. World Health Organization. Guidelines on co-trimoxazole prophylaxis for HIV-related infections among childrens, adolescents and adults recommendation for a public health approach. Bern: World Health Organization; 2006.

[7] Beraud GS, Pierre-Francois A, Abel S, Liautaud B, Smadja D, Cabie A. Cotrimoxazol for treatment of cerebral toxoplasmosis: an observational cohord study during 1994-2006. Am J Trop Med Hyg. 2009 April; 80(4): 583-587.

[8] Laksana A S D, Lestari D W D. Faktorfaktor resiko penularan HIVIAIDS pada lakilaki dengan orientasi seks heteroseksual dan homoseksual di Purwokerto. Mandala of Health. 2010 Mei; 4(2): 113-123.

[9] Syafrizal. Hubungan kepatuhan ODHA dengan keberhasilan terapi antiretroviral (ARV) di Lantera Minangkabau support Padang tahun 2011. Padang: Sekolah Tinggi Ilmu Kesehatan Alifah Padang; 2011.

[10] Sharma S K, Mohan A, Kadhiravan T. HIVTB co-infection: epidemiologi, diagnosis \& management. Indian J Med Res. 2005 April; 2(1): 550-567.

[11] Yunihastuti E, Djauzi S, Djoerban Z. Infeksi oportunistik pada AIDS. Jakarta: Balai Penerbit FKUI; 2005.

[12] Switzerland. World Health Organization. Rapid advice antiretroviral therapy for HIV infection in adults and adolescents. Bern: World Health Organization; 2009.

[13] Murni S, Green C W, Djauzi S, Setiyanto A, Okta S. Hidup dengan HIVIAIDS. Jakarta: Yayasan Spiritia; 2009.

[14] Ghate M, Deshpande S, Tripathy S, Nene M, Gedam P, Godbole S, Thaker M, Risbud $A$, Bollinger R, Mahendale S. Incidence of common opportunistic infections in HIVinfected individuals in Pune, India: analysis by stages of immunosuppression represented by CD4 counts. Int J Infect Dist. 2009 Januari; 13(1): 1-8.

[15] Indonesia. Kementerian Kesehatan Republik Indonesia. Pedoman pelayanan kefarmasian untuk orang dengan HIVIAIDS (ODHA). Jakarta: Kementerian Kesehatan Republik Indonesia; 2006.

[16] Indonesia. Kementerian Kesehatan Republik Indonesia. Pedoman nasional tatalaksana klinis infeksi HIV dan terapi antiretroviral pada orang dewasa. Jakarta: Kementerian Kesehatan Republik Indonesia; 2011.

[17] Gunung I K, Sumantera I G M, Sawitri A A $S$, Wirawan D N. Pengantar konselor HIVIAIDS. Australia: Public Health Limited; 2003.

[18] Sanjaya A, Sugiarto C, Jonathan R. Korelasi antara total lymphocyte count dan CD4 count pada pasien HIVIAIDS. Fakultas Kedokteran Universitas kristen Maranatha. 2015 April.

[19] Lexicomp. Drug information handbook a comprehensive resource for all clinicians and healthcare profesionals. Edisi 22. Amerika: American Pharmacists Association; 2013-2014.

[20] Walker A S, Ford D, Gilks C F, Munderi P, Ssali F, Reid A, Katabira E, Grosskurth H, Mugyenyi $P$, Hakim J, Darbyshire J H, Gibb D M, Babiker A G. Daily cotrimoxazol prophylaxis in severely immunosuppressed HIV-infected adults in Afrika started on combination antiretroviral therapy: an observational analysis of the DART cohort. Lancet. 2010 Maret; 375(1): 1278-1286. 
Taufany, et al, Hubungan antara Profilaksis Kotrimoksazol dan Prevalensi Toksoplasmosis pada Pasien..

[21] Febriani N. Pola penyakit saraf pada penderita HIVIAIDS di RSUP DR. Kariadi Semarang. Semarang: EGC; 2010.

[22] Natadisastra D. Parasitologi klinik di Indonesia. dalam: parasitologi kedokteran dtinjau dari organ tubuh yang diserang. Edisi 1. Jakarta: EGC; 2009. 